\title{
Statutory Power and Agricultural Marketing: The New Zealand Experience
}

\author{
Veronica Jacobsen and Grant M. Scobie
}

$\mathrm{T}$

The marketing of a major share of New Zealand's exports is conducted within a regulatory structure that has been in place for much of this century. Agricultural exports account for more than 70 per cent of New Zealand's total merchandise exports. Of these, more than one half are influenced by statutory powers. Under these powers, agencies have been established whose functions include significant holdings in commercial ventures, $\mathrm{R} \& \mathrm{D}$, promotion, quality control and the setting of standards, allocation of access rights, and varying degrees of control over exporters (almost complete in the case of apples and pears and dairy products, partial in the case of meat, and minimal in the case of wool). Until just three years ago, price stabilisation was another of their functions.

This pattern of intervention has created a regulatory environment that restricts choice, limits competition, creates barriers to entry, encourages wasteful rent-seeking and generates signals that distort the way scarce resources are allocated (ACIL, 1992; Finlayson, 1993). Moreover, agricultural marketing regulations affect the way in which resources are used throughout the economy generally, creating a broad spectrum of stakeholders in the performance of agricultural marketing. Over the last decade, farming interests have contributed to the process of reform in non-farm sectors in New Zealand. In the same way, other sectors may legitimately consider the appropriateness of statutory power in agricultural marketing.

How can the persistence of agricultural marketing regulations be explained, especially in view of the substantial deregulation of New Zealand's economy over the last decade? And if a case is established for some type of intervention, what form might it best take?

\section{Historical Background}

Statutory marketing arrangements in New Zealand have a long history. The Dairy Industry Act 1892 was the first of a series of statutes - such as the Meat Export Control Act 1921/22, the Fruit Control Act 1926, and the Wool Board established in 1944 - that eventually covered most of New Zealand's agricultural exports. They had different powers but all were backed by legislation. The creation of the Kiwifruit

Veronica Jacobsen is Lecturer, and Grant Scobie Professor, in the Department of Economics at the University of Waikato. 
Authority in 1977 continued the established pattern and extended it to non-traditional exports.

Almost without exception, the marketing agencies were set up in response to depressed prices. Little if any analysis was undertaken of the underlying causes, nor was any consideration given to other possible policy responses. Producers, dissatisfied with the returns they were receiving, felt typically either that international prices were inequitable, or that their shares of the world price were unjustly low. Producercontrolled statutory marketing authorities seemed the appropriate response to both problems, by providing producers with countervailing market power and enabling them to avoid the excessive costs imposed by 'middle-men' .

But what explains the persistence of the statutory powers for agricultural marketing? One explanation, an 'efficiency hypothesis', is that they are a response to market failure that lead to more efficient outcomes, and are hence justified by reference to the public interest. Another explanation is that, like all interventions, statutory powers for agricultural marketing create winners and losers, and that the winners succeed in the political market in having statutory powers retained at the expense of the losers. These two explanations are examined in turn.

\section{The 'Weak Selling' Explanation}

The traditional case for statutory power in agricultural marketing is that it is a response to 'weak selling', a form of market failure. According to the chairman of the Apple and Pear Marketing Board, weak selling occurs when 'an exporter . . . accepts a lower price than that which could, and should have been achieved. This action could also result in a generally lower price level being established for that product across the market' (Pope, 1988:39). The concern is that there exists a market premium that, in the absence of state-imposed collusion, will be eroded away by competing New Zealand suppliers.

Yet the fact that the observed price is low (however that might be measured) cannot of itself be taken as evidence of weak selling. The market price actually paid is composed of three elements. The first is the underlying element of price that reflects the supply and demand conditions in the market at the time. The second is a premium for value added through quality, packaging, delivery, credit or goodwill. Third, there may be a premium for market power, which economists call a 'monopoly rent'.

A particular seller or selling country is typically unable to affect the underlying market conditions that lead to a low price. However, it is possible to attain a higher price in the market through the provision of marketing services or value-adding activities. There is nothing intrinsically superior about attaining a higher price in this way: 'price premiums clearly can be obtained from market differentiation backed up by services targeted on those markets' (Industry Commission, 1991:46). Whether the pursuit of such premia is justified is a commercial decision best left in the hands of individual exporters.

This leaves the third component of price - monopoly rent - as the only legitimate concern in the weak-selling debate. It is true that if there exists some market power that might be exploited to enhance returns, failure to restrict access can result in 
the dissipation of the rent by competing suppliers. Were New Zealand to be the only supplier of a particular product for which consumers had few if any substitutes, then the standard argument for an optimal tariff would apply. That tariff, or, more precisely, export tax, should be set so as to capture the benefits of the monopoly power. The size of the tax, whose purpose would be to restrict supplies to the export market, would be inversely proportional to the (absolute) elasticity of demand faced by New Zealand exporters.

Such evidence as there is (Scobie, 1973) indicates that New Zealand is not so blessed. But suppose for a moment that it was. In order to capture the premium for market power, that power must be exercised. Its only form of expression is through the ability of New Zealand suppliers to act as a cartel to reduce supplies. On the presumption that New Zealand's share is significant enough, then the world price would rise. However, such a rise could be sustained only if there were restrictions on domestic supply. No board actually operates any explicit form of supply control. They accept whatever quantity producers offer. If they are successful in extracting a premium that is passed to producers in the form of higher prices, this will elicit more, not fewer, supplies. Attempts by the Kiwifruit Marketing Authority to restrict the export supplies through severe quality standards have arguably led to a higher per unit price for New Zealand suppliers. But that is a reflection of a quality premium (albeit one that is artificially induced) rather than of the genuine exercise of market power.

Were the boards to control domestic supplies (which they do not), extraction of market premia would still require two other conditions to be fulfilled: that consumers lacked substitutes, and other suppliers would not respond to the higher prices induced by the New Zealand cartel. The nature of New Zealand's agricultural exports are such that it is improbable that such conditions apply. Zwart and Moore compared prices received for a range of New Zealand exports with those received by other countries. They concluded, 'the evidence ... while limited, does little to support the notion that they [the boards] have provided increased returns to New Zealand producers' (1990:272). Kraft, Piggott and Wright conclude that 'any premia which are achieved [in rice exporting] are most likely payments for the services embodied in the Australian product rather than "pure profit" associated with monopoly power' (1991:ix).

The Industry Commission (1991:49) notes,

... export licensing or single-desk selling themselves can impose costs, since they limit market entry and can prevent competitive pressures from ensuring that sales into premium markets are undertaken at least cost. . . Thus the objective of capturing a market power premium on export markets through controls on competitive access would only be sound if any extra costs imposed by those controls were less than the extra income obtained.

So even if statutory intervention could capture market premia, it might still be more costly than the market failure it was designed to cure.

The structure of statutory monopolies suggests that it is. Such bodies have the power to coerce growers to pay levies. The open palm and iron fist foster a cost-plus 
mentality, and raise problems about accountability to growers (Weir, 1992). Moreover, the ownership of the boards by growers is illusory: growers do not have tradable assets reflecting their equity in these organisations (Ireland, Wallace and Associates, 1994). Commercial accountability permits owners of firms to assess the performance of a company, and to act by trading shares. With no commercial mechanisms for owners to control managers, second-best political accountability prevails. And statutory monopolies have few incentives to be efficient, since it is competition that drives firms to seek new, profitable opportunities such as new apple varieties and new lowercost methods of production to stay in business.

The costs of intervention are not always obvious. Statutory monopolies deter new entrants, and the unborn can raise no voice in opposition. Not only are the potential entrants themselves denied the opportunity to make profits, but growers are denied the benefits of competition among providers of farming services. It is the growers who should ultimately decide whether the services offered by a competing exporter are superior to those provided by the board.

Statutory monopolies also stifle the emergence of new organisations that could offer the same or similar services at lower prices. A particular problem is that producer boards act as both players and referees. The Meat Producers Board owns commercial ventures, yet influences the access to markets through the Meat Planning Council and has the ultimate power of sanction through its delegated statutory power to issue licences. The Apple and Pear Marketing Board has held a complete monopoly on apple and pear exporting. As a result of the Producer Boards Amendment Act 1993, it now sets guidelines and issues licences for competing exporters. Predictably, the guidelines are set, not to ensure efficiency, innovation and higher returns to growers, but to preserve the monopoly position of the board, which can use its role as referee to deny applications.

If New Zealand's agricultural markets are not characterised by serious failure, and if statutory intervention is costly, the 'public interest' explanation for the persistence of that intervention would appear to be refuted. In contrast, the alternative explanation, which stresses the role of private interests, seems much more consistent with the facts.

\section{The Private Interest Explanation}

The private interest explanation of the persistence of regulation focuses on the incentives that the state provides for some groups to invest in the political market in order to capture benefits in excess of those that an unfettered market system would have provided. This view of economic regulation, which emerged from the law and economics school (Stigler, 1971; Peltzman, 1976), has increasingly been used to obtain insights into agricultural-marketing regulatory system (Rausser, 1982; Sieper, 1982; Scrimgeour and Pasour, 1994).

The explanation proceeds from the fact that there are always gainers and losers from the use of the state's coercive power. Typically, the benefits are concentrated among a relatively small number of well-organised and vocal supporters, whereas the costs are generally obscure and diffused among a large number of people. Because the costs imposed on each are small (or even unknown) relative to the costs of lobby- 
ing, opposition is often weak and disorganised, even though the overall costs of the intervention may exceed the benefits. Inefficient and inequitable legislation may flow from legislators providing special status to effective interest groups who can help their electoral prospects. Edwards (1993) paints a clear picture of the political markets that control regulation in the Australian primary sector.

Where political rents are available, competing groups use resources to obtain and preserve favourable policies, and to oppose unfavourable ones. Each group has an incentive to spend up to the amount it expects to gain from its quest. Such activity is wasteful because it not merely transfers benefits and costs from one group to another, but uses up resources that could be profitably spent elsewhere. The grower levies used to fund publicity campaigns and to lobby politicians have an opportunity cost in terms of on-farm and off-farm investments.

Current attempts to reform the boards have met with limited success. Some decisive political moves by the Labour government in the late 1980 s did result in the deregulation of the town milk, eggs, wheat and flour sectors (Sandrey, 1990). Notably, all of these were non-traded or importable goods. Reform is proving much harder for the major export industries. Reforms face 'the inherent conflict between the pursuit of economic efficiency and the domination of the boards by producer representatives, who will inevitably be preoccupied by short-term political agendas as they seek to placate their constituents in farm organisations and keep the peace with politicians on whose favours their powers depend' (Watson, 1990:9).

It is not hard to find private-interest reasons why producers would support statutory powers in agricultural marketing. One is the expectation that at times of extreme adversity the state will use taxpayers' money to bail growers out. An implicit government guarantee shifts the risk of poor decision-making by producers' boards from growers to taxpayers. This 'insurance benefit' may well offset the costs of statutory power to growers. Certainly the writeoffs of debts accumulated by poor commercial judgments have been very substantial. Again, the boards allegedly protect growers from exploitation by greedy 'middle-men'. By maintaining ownership and control of processing and channels, growers feel they avoid the risk of exploitation.

However, growers' support for statutory intervention may well be artificially sustained by the boards' sophisticated public relations and control over information. The boards use the producers' own funds to convince them that their returns would fall were the boards to lose their statutory powers. Significantly, their support falls when alternative sources of information are available to producers, or when boards react strongly to counter unflattering external views of the their performance. Yet the information that the boards supply is simply not sufficient to enable to growers to assess their performance. The use of proxy indicators, such as price per unit rather than profitability to the grower, obscures their effect on the bottom line. 'Bundling', in which the profits of commercial activities are distributed as part of the price that dairy farmers receive for their milk, gives a distorted picture to growers of the board's performance. At present they have no way of distinguishing the effects of their own efforts as suppliers from the performance of their cooperatively owned processing and marketing facilities, or from conditions in world markets. They receive a return to 
their own labour and capital that is bundled together with that of returns to their offfarm investments (Hussey, 1993).

\section{Is Any Intervention Warranted?}

The economic climate, both domestic and international, is now very different from that which prevailed when the majority of the existing marketing structures were set up. In the domestic economy, the role of the state in commercial activity has been reshaped. Corporatisation or privatisation has occurred in areas where the state was traditionally the sole equity holder, maintained a monopoly position and operated with a direct line to the national fisc to cover operating losses. Social-policy goals have largely been separated from commercial activities. Decisions on investment, capital structure, pricing and marketing are now freed from political dictates, and can be driven by the need to generate market returns from providing improved services. Wage setting has been depoliticised, and employees and employers have considerable freedom in establishing contracts that serve the interests of both. In short, the provision of services is now largely a matter for market forces. Any past justification for the need for agricultural marketing agencies backed by statutory power in order to provide producers with countervailing bargaining power has been removed by the liberalisation of the domestic economy.

A parallel burgeoning of market forces in the international economy, while arguably less complete than that within the New Zealand economy, has altered dramatically the conditions facing the agricultural processing and marketing sectors. The rapid growth of international trade, the greater diversity of products and market destinations, the integration of global capital markets, and the continuing economic growth in Asia expanding the demand for imported agricultural products from the temperate zone, have all combined to change the nature of the international market place. No longer is a limited range of agricultural exports directed principally to a single market In an increasingly competitive international market, success depends on innovation, the development of new markets and products and associated services, and the formation of alliances with other players.

To what extent are the existing regulatory mechanisms, designed to address very different circumstances in both the domestic and international operating environments, still appropriate? The most obvious candidate for continued intervention is investment in R\&D. To the extent that there are benefits that cannot be appropriated by providers of R\&D services, there can be a case for collective action. New Zealand has recognised this need with the Commodities Levies Act 1991, a generic statute that allows any group, following a referendum of its constituents, to raise levies. Recent evidence from the grain industries suggests that rural trusts formed on a purely voluntary basis can be used to fund R\&D.

Beyond this, the case for statutory powers appears thin. Any group of investors can initiate a commercial venture if they believe the returns on such an investment are comparable or better than those they could command in alternative activities. Many industries impose their own quality standards and arrange their own generic promotion without statutory backing. A role for continued generic promotion of increasingly 
differentiated products produced by different companies would seem to be open to question. The combined efforts of wine producers to levy themselves voluntarily to promote New Zealand wines in Britain suggest that statutory intervention is not a nec- . essary precursor to generic promotion by exporters.

Currently, export quota rights are allocated by the Meat Planning Council under the authority of the board. In contrast, quotas for international trade have traditionally been allocated by the Ministry of Commerce. This Ministry ran the system of licensing and import quotas for New Zealand, and the revenue generated by tendering went to the Crown, not the footwear or textile industry.

In short, it is not clear that any net loss of national income would follow from the abolition of producer boards' powers. Adequate mechanisms already exist to assume certain functions. The rest are either commercial ventures or the lobbying activity of any industry group.

\section{The Future}

The last decade has seen a significant shift in the approach to statutory intervention in economic activity. In the past, reliance was placed on prescriptive legislation setting out particular goals, specifying how activities were to be controlled and disputes settled. The Acts setting up producer boards are of this type.

There is a growing awareness that granting powers to monopoly boards, with extensive reliance on accountability to Ministers through the political system, may be neither necessary nor efficient. In contrast, enabling legislation provides a framework within which individuals and groups have greater flexibility to develop mutually beneficial arrangements for allocating resources and resolving disputes. This approach is reflected in the Employment Contracts Act 1991, the Companies Act 1993, and the Commodity Levies Act 1991. This type of legislation has the potential to provide a stable framework in which voluntary transactions can take place. The evidence mounts that such an approach could enhance efficiency and accountability in the provision of marketing services for New Zealand's agricultural exports.

The persistence of inefficient statutory power can be explained only by reference to gains to special interests. However, the new domestic and international operating environment will increase the costs of intervention over time, and make them ever more obvious. Several sources of pressure signal change. Potential entrants, such as Applefields, seek to compete with statutory authorities. Producers appear to be increasingly disillusioned with the performance of the boards. A lobby group, Farmers for Change, has sought changes to the electoral procedures for grower representatives in an attempt to enhance accountability. Meanwhile, growers of fine wool have been attempting to make the Wool Board better reflect their interests. Consumers who have benefited from the freeing up of the domestic apple market and the town milk supply are increasingly aware of the benefits of deregulation.

Just as efficient markets are irrepressible, inefficient legislation is unsustainable. As the costs become apparent, pressure by lobbyists becomes irresistible. The boards are creatures of political markets. It will be economic forces operating through those same political markets that will result in change. 


\section{References}

ACIL (1992), Agricultural Marketing Regulation: Reality versus Doctrine, New Zealand Business Roundable, Wellington.

Edwards, G. (1993), 'Two Government Failures? A Tale of Sugar and Wool', Review of Marketing and Agricultural Economics 61(2): 97-112.

Finlayson, B. (1993), 'An Evaluation of Alternative Institutional Structures That Could be Utilised in the New Zealand Agricultural Industry', paper presented to the Annual Conference of the New Zealand Branch of the Australian Agricultural Economics Society, Blenheim.

Hussey, D. (1993), Agricultural Marketing Regulation: The ACIL Report Twelve Months On, New Zealand Business Roundtable, Wellington.

Industry Commission (1991), Statutory Marketing Arrangements for Primary Products., Australian Govemment Publishing Service, Canberra.

Ireland, Wallace \& Associates (1994), New Zealand Dairy Industry: Off-Farm Assets, New Zealand Business Roundtable, Wellington.

Kraft, D., R. Piggott \& V. Wright (1991), Review of the Rationale for the Rice Marketing Boand, Centre for Advanced Training in Agricultural Fconomics, University of New England, Armidale.

Peltzman, S. (1976), 'Toward a More General Theory of Regulation', Journal of Law and Economics 18: $745-71$.

Pope, C. (1988), 'Commentary' in The Producer Board Seminar Papers, Institute of Policy Studies, Victoria University of Wellington.

Rausser, G. (1982), 'Political Economic Markets: PERTS and PESTS in Food and Agriculture.', Amencan Joumal of Agricultural Economics 64: 821-33.

Sandrey, R. (1990), 'Deregulation: Selected Case Studies', Ch. 7 in R. Sandrey \& R. Reynolds (eds), Farming Without Subsidies, GP Books, Wellington:

Scobie, G. (1973), 'The Price Elasticity of Demand for New Zealand Exports: Theory and Estimation', New Zealand Economic Papers 7: 1-24.

Scrimgeour, F. \& E. Pasour, Jr (1994), 'The Public Choice Revolution and New Zealand Farm Policy', Review of Marketing and Agricultural Economics 62: 273-83.

Sieper, E. (1982), Rationalising Rustic Regulation, Centre for Independent Studies, Sydney.

Stigler, G. (1971), 'The Theory of Economic Regulation', Bell Journal of Economics and Management Science 2(1): 1-21.

Watson, A. (1990), Unravelling Intervention in the Wool Industry, Centre for Independent Studies, Sydney.

Weir, R. (1992), 'Electoral and Accountability Review Report', NZ Meat Producers' Board and NZ Wool Board, Wellington.

Woods, R. (1988), 'The Statutory Powers of the Producer Marketing Organisations', in The Producer Baard Seminar Papers, Institute of Policy Studies, Victoria University of Wellington.

Zwart, A. \& W. Moore (1990), 'Marketing and Processing', Ch. 13 in R. Sandrey \& R. Reynolds (eds), Farming Without Subsidies, GP Books, Wellington. 